\title{
At frigøre (sig fra) mors begær \\ - Om Lars von Triers Antichrist
}

Det var meget forudsigeligt, at Lars von Triers Antichrist (2009) skulle vække en bitterhed, der kaldte sig feministisk og beskyldte filmen for at være kvindefjendsk. Maria Sveland og Katarina Wennstram mente i Dagens Nybeter (28/7 2009), at filmen handler om en kvinde, der lemlæstes og straffes for at have egen lyst og forstand. Kvinfos direktør Elisabeth Møller Jensen mente, at filmen "bekræfter og legitimerer den seksualiserede vold mod kvinder" (Politiken 23/6 2009). Jette Hansen var i sin kronik i Politiken (12/7 2009) klog nok til at betragte filmen som en undersøgelse af kønskampen frem for et partsindlæg i den, men hun tog så parti mod filmens mandlige karakter (Willem Dafoe), som ifølge Hansen hellere skulle gå i dialog med sin kvinde end slå hende ihjel. Hansen insisterede på en (angiveligt kvindelig) tematisk fortolkning, som skulle stå i modsætning til en (angiveligt mandlig) æstetisk analyse - og ignorerede dermed, at et kunstværks "betydning" skabes lige så vel af dets æstetiske form som af dets tema. Men er der ikke noget om snakken? Er von Triers forrygende antikristelige gestus af en film ikke også en antifeministisk gestus? Handler den måske ikke om en mor, der lader sit barn dø, fordi hun angiveligt har travlt med at tilfredsstille sit eget begær? Endda en mor, hvis forskning $\mathrm{i}$ historisk kvindehad har drevet hende til den konklusion, at kvinden faktisk er ond. Og ender den ikke med et kvindedrab? Et drab, som tilskueren må sympatisere med, fordi ingen af os i længden kan holde ud at se og høre Charlotte Gainsbourg rende rundt og være hysterisk.

Jo, det gør den. Men kvinden fremstilles hverken som mere eller mindre ond end den natur, både hun og manden er en del af. Og filmens kunstneriske logik gør det naivt at forstå personerne som psykologiske portrætter af selvstændige individer, der kan karakteriseres eller dømmes som sådanne, det være sig af tilskueren eller af filmen selv. 


\section{Drømmens æstetik}

Selv om Gainsbourg i en af filmens replikker erklærer Freud for død, synes filmen at være på bølgelængde med Freuds forståelse af, hvordan menneskesindet drives af kræfter, som er stærkere end livet selv. Den kognitive terapi-teknik, som Dafoe først forsøger at behandle sin sørgende og skyldplagede hustru med, spiller fuldstændig fallit over for disse kræfter. Til gengæld synes filmens billeder at være i inderlig slægt med de fantasiog drømmebilleder, som Freud udforskede med sin psykoanalyse. Æstetikken i Antichrist er en drømmens æstetik og indskriver sig dermed i et filmhistorisk slægtskab med Ingmar Bergman og med Andrej Tarkovskij, som filmen er dedikeret til. Drømmens personer er altid drømmeren selv, hævder Freud. En sætning, der giver mening om kunstværker generelt og om Anticbrist specifikt: personerne er dimensioner ved én og samme bevidsthed frem for selvstændige individer, der kan behandles som portrætter af virkelige personer. Man kan også sige det på en anden måde: $\mathrm{i}$ Anticbrist forbliver personerne koreografiske positioner, som ikke tilbyder os affektive identifikationer. At feministiske kritikere så affektivt har identificeret sig med Gainsbourg som den undertrykte, for ondskab beskyldte kvinde, siger mere om deres måde at forholde sig til kunst på, end det siger om filmen. Skal man absolut tale om affektive identifikationer, kan man anføre, at Trier selv har udtalt, at hvis der er nogen person, han identificerer sig med i filmen, er det kvinden. (Lykkeberg 2009)

\section{Det befriede ansigt}

Filmens drømmexstetik giver os det ene fantastiske billede efter det andet, kulminerende med den magiske og mangetydige "epilog". Efter at vi på barok, allegorisk vis har været igennem sorgen, smerten, fortvivlelsen, klitoriskastrationen og kvindedrabet, får vi en "epilog", hvor Willem Dafoe er på vej bort fra hytten i den gudsforladte natur, som han efter sønnens død har opsøgt sammen med sin nu strangulerede og på bålet brændte hustru. Han går og spiser bær, som han plukker af buskene - og som tilskuer bliver man klar over, at man hidtil ikke har set personerne spise noget som helst. Da han løfter ansigtet og skuer frem, er det et befriet ansigt vi ser. En scene, der synes at være en hilsen til et af filmhistoriens stærkeste billeder af et befriet ansigt: Victor Sjöström, som i slutningen af Bergmans Smultronstället lader sit bitre gammelmandsansigt udglattes i smilende åbenhed, som en knyttet hånd, der åbner sig og rækker ud mod verden. 
I Smultronstället har det befriede ansigt i et drømmesyn fået øje på den gamle mands far og mor, unge som $\mathrm{i}$ hans barndom: smilende, vinkende $\mathrm{i}$ skærgårdens sommer. I Antichrist er det også et drømmesyn, Dafoes befriede ansigt skuer, men af tvetydig karakter: En skare af kvinder med slørede ansigter, ubestemmelige i alder og epoke, myldrer frem af skoven og op og ned ad en bakke. Det er malerisk skønt, men giver samtidig mindelser om et af filmens tidligere billeder af den faldne natur: myrer, der myldrer hen over en død fugleunge i kløerne på en rovfugl.

Det er umuligt at afgøre, om kvinderne kommer for at hævne sig på manden, om de kommer for at tilgive ham eller om de bare har med sig selv at skaffe, med manden som ren iagttager. Denne uafgørlighed forstærkes af den uafgørlighed i synsvinklen, som klipning og kameraføring bevirker - det er faktisk svært at lokalisere kvinderne i forhold til manden. Kommer de mod ham eller bag om ham, er de på vej op eller ned, står han over eller under dem? Kvindernes slørede ansigter kan give dem karakter af noget umenneskeligt, men kan også ses som et emblem på den ansigtsløshed, der ifølge filosoffer

som Slavoj Žižek og Giorgio Agamben kendetegner "næsten". "Næsten" har ikke noget ansigt, er ikke nogen genkendelig spejlingsflade for dine egne følelser, men et uigennemtrængeligt nærvær af noget fremmed ved din side.

Måske er ansigtsløsheden tegn på, at kvinderne repræsenterer den "næste", som manden, af kærlighed, i sin hustrus skikkelse, har måttet slå ihjel. Måske er den tegn på, at de som myrerne repræsenterer naturens blinde kræfter. Måske er den tegn på, at de er anonyme og hævnende zombies, der stiger op af kvindemordenes massegrav. Måske er bakken en Golgatha-høj og Dafoe en Kristus på vej til at bestige den, for på hele sit køns (og mange af sine tidligere filmrollers) vegne at sone (film)historiens forbrydelser mod kvindekønnet, som Kristus tager hele menneskeslægtens synd på sig. Den sidste tolkningsmulighed burde én gang for alle lukke munden på de overfladiske tolkere, der anklager Antichrist for at være antifeministisk.

\section{Affekt eller allegori}

Efter at have set Antichrist første gang, forstod jeg ikke beretningerne fra Cannes-festivalen om, hvordan en del af tilskuerne havde forladt filmen i vrede og i kvalme. Ganske vist ser man en kvinde bore et dybt hul i sin mands ben, smadre hans testikler og derefter klippe sin klitoris af, man ser en hind med et dødt foster hængende ud af bugen, man ser en ræv skambide sig selv og en lille nøgen fugleunge dækket af vrimlende myrer i en rovfugls 
kløer. Men for mig overdøvedes den kvalme, som sådanne billeder kan tænkes at fremkalde, af filmens udpræget allegoriske karakter. Dvs. det at filmen i så høj grad fremviser sine billeder som tegn, der skal tolkes, frem for som umiddelbare sanseoplevelser. På den ene side skildrer filmen en rå natur, blottet for enhver form for mening; på den anden side skildrer den en natur, hvor alt er blevet til tegn, hvor fauna, flora, stjernebilleder og menneskekød er koder, der skal knækkes, pumpet op med kulturelle referencer - til Kristus, til Ødipus, til Freud, til Nietzsche, til Satan, til Bergman, til Tarkovskij. I den forstand er vi i Antichrist i et univers, der i udpræget grad ligner barokkens. I det barokke verdensbillede er naturen falden; flora og fauna og menneskekød er fuldstændig adskilt fra Gud, men tømt for guddommelig mening henligger deres lemmer og elementer til gengæld til fri afbenyttelse som tegn i menneskets kulturelle alfabeter.

I et barokt univers, hvor Gud er radikalt adskilt fra menneskenes og naturens verden, er hverken betydning eller forløsning noget, der indfinder sig af sig selv. I de barokke tragedier indfandt forløsningen sig ikke som en naturlig udvikling af plottet, men som en "deus ex machina", en udefrakommende instans, der unaturligt og usandsynligt trådte ind på scenen og frembragte en lykkelig slutning. I Antichrist får ravnen en sådan deus ex machina-funktion mod filmens slutning: Den skræpper op under gulvbrædderne på det sted, hvor svensknøglen ligger, så Dafoe kan bryde gulvet op med sin albue og fremdrage det redskab, der kan befri ham.

Helt barokt allegorisk fremstilles de tre begreber, som har lagt titel til filmens tre kapitler: sorg, smerte og fortvivlelse. I filmens prolog står tre statuetter med disse inskriptioner på bordet hos den lille søn, som fejer dem ned, da han klatrer op for at styrte sig ud ad vinduet. Og i filmens løb bliver ræven, hinden og ravnen til emblemer for disse tre affekter - ikke fordi vi intuitivt oplever dyrene som symboler på affekterne, men fordi de tildeles denne tegnværdi i kvindens afhandlings-noter, som manden finder på loftet. Det er netop sådan, den barokke allegori siden Goethe er blevet defineret til forskel fra det romantisk-klassiske symbol: hvor allegoriens tegnværdi bogstaveres for læseren/tilskueren ("ræv=sorg"), skal symbolets tegnværdi intuitivt sanses (som hvis vi ved synet af ræven intuitivt blev grebet af en ubestemmelig sørgmodig følelse). Allegorien hører hjemme $i$ et univers, hvor naturens genstande kun bliver betydende, når den menneskelige bevidsthed lægger en mening ind i dem, idet de ikke er gennemtrængt af en (guddommelig sanktioneret) betydning, som den dermed forbundne menneskelige bevidsthed intuitivt kan fornemme. 
Jeg skal ikke gøre mig blind for, at allegorisk tolkning i forvejen er en stærk trang hos mig, og at den kan fungere som et forsvar mod angst- og kvalmefremkaldende billeder. At jeg i en høj alder har gennemført at se alle de Hitchcock-film, jeg ellers aldrig har turdet se, har kun kunnet lade sig gøre, fordi jeg har slået min tegn-aflæsende hjerne til og tolket, tolket, tolket. Kun på den måde har jeg undgået at drukne i Vertigo's angsthvirvler eller sønderhakkes af de spidse næb i Fuglene.

Jeg skal altså ikke udelukke, at mit syn på Antichrist som en meget allegorisk film, der kalder på tegntolkning frem for kvalme og angst, er en måde at forsvare mig mod kvalmen og angsten på. Jeg skal heller ikke skjule, at jeg faktisk aldrig har set de værste billeder i Antichrist, men har lukket øjnene under ben-gennemboring, testikel-smadring og klitorektomi. Og endelig kan jeg ikke ignorere, at slutscenen fremkalder en følelse af renselse i mig - en følelse, der tyder på, at jeg har været gennem stærke affekter trods min vægring mod at se.

\section{Anti-krist eller Krist}

Hvorfor hedder filmen Antichrist? Lars von Trier har selv anført, at han længe har haft Nietzsches bog med denne titel liggende på sit natbord, men at det først og fremmest er en skidegod filmtitel. Filmen er anti-kristelig $i$ den forstand, at den skildrer en natur og et menneskekød der ikke er befriet af nogen Messias; et univers, hvor syndefaldet aldrig er blevet godtgjort af en guddommelig menneskesøns soning. Det er med satanisk ironi, at parrets sted på landet hedder "Eden", Paradisets have, for vi befinder os på ingen måde før syndefaldet i dette bregne-overgroede, forrådnende vildnis. Tværtimod befinder vi os i noget, der ligner et permanent, uophørligt syndefald i form af en natur, der bliver ved og ved med at falde, som de agern, der bliver ved med at falde på hyttens tag med en enerverende lyd. Sjældent har man set så anti-romantisk en fremstilling af en gudsforladt natur. En fremstilling, der begynder, da kameraet $i$ hospitals-scenen zoomer ind på de lodne stilke $\mathrm{i}$ blomstervasen ved siden af kvindens sygeseng, og tilskueren opdager at den stiliserede natur (buketten) ved nærmere eftersyn er ved at opløse sig i fugtig forrådnelse.

I en vis forstand står naturen altså for død og forrådnelse i filmen, men man kan med lige så stor ret sige, at den står for det, der ikke vil dø, det som Lacan ville kalde "det reelle". Det dumpe, spøgelsesagtige liv, der bliver ved med at pulsere hinsides al mening. Som ravnen i den tomme rævehule, hvor Dafoe slæber sig hen med den møllesten, som Gainsbourg har boret fast til hans ben. Den tomme rævehule kan indikere Kristi grav, og med sit gennem- 
borede ben fremstår han som en gennemnaglet Kristus, hvilket understreges, da en sten falder for indgangen, som stenen for Jesu grav. På sin vis bliver han også vidne til en "genopstandelse" i graven, men det er ikke en forløsende transformation af kødet til ånd gennem døden; det er tværtimod skræmmende, fysisk liv, som nægter at dø, i skikkelse af ravnen, der tilsyneladende ligger død i hulen, men viser sig at være i live og med hakken og hæse skrig modstår hans ihærdige forsøg på at slå den ihjel.

For den østrigske forfatter Elfriede Jelinek, som har skrevet forrygende begejstret om Antichrist i filmtidsskriftet Cargo, betyder Anti-Krist, at kærligheden (Kristus) er væk, og magten hersker (Jelinek 2009: 14). Den magt, som er naturens kraft, men som naturvæsenerne (dyrene) udøver uden skyld, mens menneskene bliver skyldige af at udøve magt. Med barnets død i starten ser Jelinek Gud trække sit skaberværk tilbage (Jelinek 2009: 12).

Som Satan kan titlens "Antikrist" siges at være emblemet for den faldne natur. Men snarere end Antikrist-myten synes filmen egentlig at referere til Lucifer-myten: Djævlen som den faldne lysengel, der ifølge gnosticismen har skabt menneskene og verden. I den smukke prologs billeder af barnets fald gennem en hvirvel af lysende snefnug er det således muligt at se en hilsen til myten om den styrtende lysengel. Og måske endda, som Jelinek, at betragte lysenglen som filmkunstens gud. ('Film er lys og skygge, lyst og mørkt!” Jelinek 2009:14).

Snarere end en direkte henvisning til myten om Antikrist kan titlens "anti" forstås som den gestus, hvormed filmen jonglerer med vor kulturs grundmyter. Ikke alene Kristus og genopstandelsen, men også Ødipus og den freudianske urscene, vendes på vrangen og på hovedet - og det kan måske i sig selv ses som en "satanisk" gestus: at vende de hellige symboler på hovedet.

\section{Antichrist som tragedie}

Snarere end dødens sted bliver "Eden" det sted, hvor man ikke kan dø. Som Jelinek skriver, er døden her ingen bortgang, men noget man fastholdes i: "Her skal døden være en forbliven og en beholden" (Jelinek 2009:12). De to personer, der ankommer til "Eden", kan siges at være afgået ved døden som mennesker i den sociale verden - i kraft af sønnens død er de slynget ud af den rolle og funktion, de plejer at udfylde i samfundet og livet; ikke engang et navn har de. Mellem denne sociale "død" 
og den biologiske død, som slutteligt indfinder sig for hende, befinder vi os $\mathrm{i}$ den zone, hvor behjertet terapeut-snak bliver tom tale; hvor kommunikation ikke foregår i ord, men i kød og blod; hvor kræfter stærkere end selvopretholdelsen driver menneskets gerninger. Denne zone er det tragiskes zone det er den samme zone, den græske tragedieheltinde Antigone befinder sig i, da hun udstødes af samfundet af kong Kreon, fordi hun insisterer på at begrave sin døde bror, skønt han har kæmpet på fjendens side. Mellem Antigones død som samfundsborger og hendes biologiske død ligger den zone, hvor hun handler med den tragiske helts nødvendighed og gør, hvad hun må gøre, selvom det er imod både samfundets og selvopretholdelsens love. Det er denne zone, Lacan i seminar VII kalder 'l'entre-deux-morts", mellem to slags død, og i denne zone befinder også Triers personer sig, hvorved hans film får samme kunstneriske karat som en antik tragedie. Som en tragedie fremkalder filmen også den form for renselse, som de gamle grækere kaldte "katharsis". Og som en tragedie dirrer filmen i en højspænding mellem det grusomme og det skønne, det dionysiske og det apollinske, det reelle og det symbolsk-imaginære. I Die Geburt der Tragödie aus dem Geiste der Musik definerer Nietzsche tragedien som dér hvor det dionysiske (smertens og nydelsens store og formløse urgrund, som vi ville dø af at opleve ufiltreret) og det apollinske (det formgivende, gestaltende princip) holder hinanden i skak med en voldsom kraft, som afkaster den højst tænkelige æstetiske effekt. Med Lacans begreber svarer det dionysiske til "det reelle", mens det apollinske svarer til det symbolsk-imaginære, dvs. den måde hvorpå vi gennem konventionelle ord, billeder, modeller såvel som sociale og private fantasier giver form og gestalt til verden. Også for Lacan er der i det tragiske en højspænding mellem (symbolsk-imaginær) form og (reel) formløshed. Som han læser Antigone-skikkelsen i seminar VII, får denne tragiske heltinde sin bevægende skønhed (som ligefrem giver Lacans "tredje øje" erektion, Lacan 1986: 295!) netop af at befinde sig dér hvor det symbolsk-imaginære med nød og næppe holder stand over for det reelle; dér hvor bystaten vakler i sin grundvold og gennemtrænges af stanken fra Polyneikes' ubegravede lig. Lacan sammenligner Antigones gestalt med barokkens anamorfe cylinder-malerier: set gennem den optiske cylinder rejser den skønneste (imaginære) gestalt sig af en "temmelig udtværet og ulækker" farveplamage (det reelle) (Lacan 1986: 318).

På samme måde som de gamle græske tragedier balancerer Antichrist lige netop dér, hvor trykket fra den formløse, ubærlige urgrund er lige så stærkt som modtrykket fra det formgivende princip, dér hvor den allerstørste æstetiske effekt opstår. For mig at se er modsætningen mellem det grumme og 
det skønne den højspænding, der sitrer stærkest i Antichrist, stærkere end den modsætning mellem natur (kvinde/dyr) og civilisation (mand), som Elfriede Jelinek gør til nøgle i sin oplysningsdialektiske tolkning af filmen. Når Jelinek i filmens sort-hvide "prolog" hører Händels arie "Lascia ch'o pianga" til de reklamexstetiske billeder af forældrenes samleje og barnets fald, hører hun den som et kontrapunkt til "de stønnendes lyst"; musikken betragter hun som "det modsatte af Natur" (Jelinek 2009: 12). Når jeg hører arien, er det snarere modsætningen mellem det skønne og det grumme, der vibrerer i mig: vi får de skønneste billeder af den grummeste begivenhed (barnets død under forældrenes samleje) og dertil en klagesang ('Lad mig klage", synger Händels sopran), som lader stor smerte få udtryk i skønne toner.

\section{(Anti)Kristus eller (Anti)Ødipus}

"Freud er død". Men Antichrist overbeviser os om, at Freud er en af de skikkelser, der ikke vil dø. Filmen er en drøm, og dens personer udgår som drømmens fra én og samme bevidsthed. Filmen kan ses som én lang udfoldelse af det, Freud kaldte "urscenen", nemlig det lille barns forestilling om forældrenes samleje (hvad enten den er ren fantasi eller bygger på en overværelse af dette samleje). En forestilling, der i billeder søger svar på oprindelsens gåde: Hvor kommer jeg fra? Af hvilket begær blev jeg født?

Antichrist åbner med en regelret urscene: forældrene har sex i badeværelset, det lille barn vågner, lister ud af sin seng og ser dem. Men hvilken urscene! Hvilke billeder! I ultra slow motion og underskønne, sort-hvide close ups fremstilles elskovsakten så erotisk, at selv det indklippede "meat shot" bliver et smukt, smukt billede, akkompagneret af Händel'sk englelyd. Og da den lille dreng vender sig fra synet, ser han lykkelig, befriet, nærmest frelst ud og vandrer målrettet hen mod det åbne vindue, hvor han kaster sig ud som en fredfyldt engel. (Det befriede ansigt, først sønnens, siden faderens, synes således at indramme filmen). Drengens fald klippes sammen med forældrenes seksuelle fryd. Drengen svajer sig som moderen og krummer sig som faderen. Hans billede gøres ét med deres, så hans blide snefnug-polstrede fald mod døden løber sammen med forældrenes fald mod orgasmen. Det er urscenen som frelse, urscenen som velsignelse, barnets mareridt forvandlet til de smukkeste drømmebilleder.

For så vidt kan man sige, at resten af filmen handler om at give os den grumme version af urscenen, nu med tilskueren i rollen som det lille barn. 
Fra sorg gennem smerte til fortvivlelse arbejder vi os frem mod det sammenfald af sex og mord, som er det lille barns fantasi om den voksne seksualitet. Tilskueren befinder sig i samme position som barnet, der overværer forældrenes samleje: udsat for gådefulde billeder af mandens og kvindens kroppe, der omgås brutalt med hinanden; blottet for den erotik, der kan give kroppenes kamp mening og skønhed.

Denne urscene er ikke bare Freuds urscene, men selve filmkunstens urscene. At være tilskuer til en film er at være passivt udsat for billeder, som man ikke selv har bedt om at få smidt i hovedet. Glem alt om feministiske filmteorier, der udnævner tilskuerens blik til at være det beherskende, falliske blik. Er man tilskuer til Triers Antichrist er man ikke fallisk beherskende, men afmægtigt udsat for billeder af det skønneste skønne og det grummeste grumme. Glem derfor også, måske ikke alt, men det meste om feministisk kritik af von Triers kvindebilleder. Nok fremstiller filmen på sin vis kvindens begær som roden til alt ondt, og Charlotte Gainsbourgs kvindeskikkelse gennemspiller stereotyperne fra hysteriker til heks. Men Willem Dafoes mandeskikkelse, svævende mellem Kristus og Anti-krist, mellem sadist og offer for den kvindelige seksualitet, er ikke mindre tvetydig. Og begge er de drømmebilleder, som tilskueren udsættes for og (trods stor allegorisk distance) glimtvis kan identificere sig med, som barnet i faldet identificerer sig snart med moderens svajning, snart med faderens krumning. Endelig er det, blandt andre udlægninger, muligt at se slutscenen som den ansigtsløse kvindeskares hævn over manden - en hævn, der ikke mindst fremstår berettiget gennem castingen af Willem Dafoe, der så ofte har haft den mandlige sadists rolle på lærredet.

"Han kan filme kærlighed som mord og mord som kærlighed", sagde Truffaut om Hitchcock. Og pegede hermed ikke bare præcist på et særtræk ved Hitchcock, men noget essentielt ved filmkunsten overhovedet. Nemlig at dens urscene er den samme som den freudianske. At være passivt udsat for billeder, som tilskueren i den mørke biografsal, svarer til at være udsat for billeder af voksen seksualitet, der for det lille barn ser mere ud som mord end som kærlighed.

Hvis der efter barnets død er en person, der bærer barnets perspektiv videre (det perspektiv, som også er tilskuerens), er det manden. Eller man skal måske sige det sådan: det skrækindjagende syn, som barnet ifølge den konventionelle urscene burde have haft (men som forunderligt forvandles til et befriende syn), præsenterer sig i det følgende dels for tilskueren, dels for manden. I naturen (den hæslige, gudsforladte ...) åbenbarer de tre dyr sig ét efter ét for ham: hinden med et dødfødt kid dinglende ud af underlivet, ræven, der har 
bidt et stort åbent sår i sig selv, en sort og skrigende ravn. Alle tre "åbenbaringer" fremstilles med pludselighedens chok-effekt og kan betragtes som den rå, kødelige, blodige dimension ved urscenen, som helt er udeladt $\mathrm{i}$ indledningens "skønne" version.

De tre dyr svæver et eller andet helt sindssygt og genialt sted mellem uhyggelige, allegoriske billeder og Disneys juleshow. Der indlægges ikke alene en henvisning til, at de står for sorg, smerte og fortvivlelse, men også at deres samtidige tilsynekomst står for død - så da de mod filmens slutning træder ind i hytten, ved vi godt hvad klokken er slået (nemlig: urscenens fuldbyrdelse i drab), samtidig med at vi et øjeblik kan tro, vi er til julebal hos Snehvide.

Den afmægtigt udsatte position (barnets, tilskuerens, mandens) bliver i filmen også en Kristus-position. Willem Dafoe bliver både stigmatiseret (af igler), mere eller mindre korsfæstet (af kvinden) og herefter anbragt i (ræve)graven med den store sten for indgangen. Antikristisk vrangvendt bliver myten, da Charlotte Gainsbourg ikke kan finde den mand, hun har korsfæstet og som en grotesk Maria Magdalena går rundt og skriger: "Hvor er du? Hvor er du?", indtil hun bevæbnet med spade (som hin gartner, der så den genopstandne Jesus?) giver sig til at grave ham ud af graven.

Også kvinden kommer $\mathrm{i}$ en af filmens sekvenser til at repræsentere den passivt manipulerede position, der kan betragtes som en allegori på tilskuerens. Det er da manden, i rollen som hendes terapeut, på vej i toget til hytten hypnotiserer hende. Hypnosen er et genkommende Trier-tema og kan også ses som et billede på det, en film gør ved sin tilskuer. I Antichrist fremkalder hypnosen en billedserie af drømmerisk Tarkovskij-skønhed tilsat et skud Peter Greenaway, da Gainsbourg i sin hypnotiske fantasi smelter fuldstændig sammen med den natur hun er bange for - lægger sig ned i græsset og bliver grøn. Igen: en skøn drømmeversion af billeder, som vi senere skal se udfoldet i rædselsvækkende råhed. Den grønne kvinde harmonisk dækket af naturens grønne element får sit brutale billed-ekko i en styrtende fugleunge dækket af fluer, som selvfølgelig også er det brutale kontrapunkt til drengens englefald gennem snefnug. Og også mandens udstrakte, gennemnaglede Kristus-krop kan ses som et brutalt billed-ekko til hypnosens udstrakte kvindekrop i græsset.

Skulle man, trods hele filmens urscene-karakter stadig tro, at Freud er død, bliver det virkelig svært, da urscenen fuldbyrdes ikke alene i drab, men også i kastration. Mandens og kvindens gensidige ødelæggelse af hinanden har vi kendt i hvert fald siden Strindberg, men von Trier nøjes na- 
turligvis ikke med at lade den udspille sig verbalt. Den skal realiseres i kød og blod og inkluderer et billede af en penis, der græder blodtårer.

Her indskriver filmen sig i hele den passion for det reelle, som kendetegner kunsten (og i bredere forstand kulturen) i dag: vi vil have "the real thing", det rå kød, ind under huden. "A bite of the real", som den lacanianske kulturanalytiker Juliet Flower Maccannell har kaldt det i sin analyse af den nyeste version af Cape Fear, hvor den psykopatiske voldsforbryder (Robert de Niro) rent faktisk tager en bid af sit offers kind, så det blodige ansigtskød blottes (MacCannell 2004: 78).

Men hvad er det for en befrielse sønnen erfarer? Hvorfor ligner hans urscene ikke mareridt, men frelse? Man kunne vove den påstand, at han befries fra moderens begær. Han ser, at moderen kan få sit begær tilfredsstillet af sin voksne mand, og i Freuds Ødipusmyte er det ganske vist et syn, der kan fremkalde afmægtig jalousi og faderdrabsfantasier, men set $i$ et andet perspektiv befrier det barnet fra at være den, der skal tilfredsstille moderen.

Moderens krav på sønnen tematiseres i filmens Ødipus-symbolik: den lille drengs fodknogler viser sig at være lettere deforme, hvilket kan ses som et ekko af Ødipus' knuste fod, og det er moderen, der har forårsaget deformiteten ved konsekvent at give sin søn skoene omvendt på. Læst sammen med hendes udtalte beklagelse over, at hendes lille søn var på vej væk fra hende længe før han døde, bliver den deforme fod udtryk for moderens deformerende ønske om at fastholde barnet (hvor den i Ødipus-myten er udtryk for det modsatte: faderens adskillelse af barnet fra moderen). Dafoes gennemborede ben bliver en voldsommere variant af denne ganghæmning, af et kvindeligt eller moderligt begær, der er parat til at deformere sit objekt for at fastholde det.

I et flash back senere $\mathrm{i}$ filmen fremstilles det som om kvinden faktisk så sin søn på vej op mod vinduet, men valgte at koncentrere sig om sin orgasme. Men dette flash back har samme drømmeagtighed over sig som resten af filmen og kan ikke entydigt udlægges som en "sandhed"; det kan lige så vel forstås som endnu en fantasi, moderens eller filmens ...

Snarere end historien om, at moderen er parat til at ofre sin søn for at få tilfredsstillet sit begær, er det historien om, at sønnen befries fra moderens begær. Vi behøver ikke læse hans fald som en død, vi kan læse det som en befrielse. Så har Kristus (befrielsen gennem noget der ligner død) vundet, men kun gennem Anti-Kristus (kun ved at vende symbolerne på hovedet).

Men er den feministiske kritik af Antichrist så alligevel ikke berettiget, omend på et andet grundlag end det, den påkalder sig? Er det ikke et problem, 
at filmen fremstiller det moderlige begær som noget, man skal befries fra? Eller kunne man forestille sig, at også det kvindelige begær kunne befries, hvis det blev befriet fra sin binding til sønnen og sin separationsangst?

Under alle omstændigheder må vi moderere den forestilling, at Antichrist handler om forældre, der bearbejder tabet af deres barn. Den handler mindst lige så meget om en søn, der bearbejder sine forældres seksualitet. Mere end den lille søns død handler den om at være søn af den lille død.

\section{Litteratur}

Jelinek, Elfriede (2009): "Und bist du nicht willig, so brauch ich Gewalt", CARGO 03/2009.

Lacan, Jacques (1986): Le séminaire, livre VII: L'ethique de la psychanalyse, Paris : Editions du Seuil.

Lykkeberg, Rune (2009): “Jeg kan godt lide, når det bliver ubehageligt”, Dagbladet Information, 19. juni 2009.

MacCannell, Juliet Flower (2004): "Between the two Fears" i McGowan \& Kunkle (red.): Lacan and Contemporary Film, New York: Other Press.

Nietzsche, Friedrich (1872 [1986]): Die Geburt der Tragödie aus dem Geiste der Musik, Stuttgart: Reclam. 